\title{
KŁAMANIE JAKO AKT MOWY - KILKA UWAG Z PERSPEKTYWY FILOZOFICZNO-PRAWNEJ
}

\begin{abstract}
Streszczenie. W artykule przedstawiono zagadnienia dotyczące analizy natury (istoty) kłamstwa z perspektywy pragmatyki logicznej. Wnioski skonfrontowano z wybranymi instytucjami prawa cywilnego w celu wykazania, jak prawo i orzecznictwo postrzegają różne formy kłamstwa, występujące na gruncie prawa pozytywnego.
\end{abstract}

Słowa kluczowe: kłamstwo, akt mowy, prawda, intencja, Kodeks cywilny.

Kłamiemy z różnych przyczyn: grzecznościowych, ze względu na chęć uniknięcia kary, dla własnych korzyści, aby się zemścić itd. Powodów jest tyle, ile kłamstw. Mimo powszechności tego zjawiska mało jest opracowań poświęconych stricte fenomenowi kłamstwa. W każdej kulturze kłamanie spotyka się z ostracyzmem społecznym, a równolegle istnieje na nie społeczne przyzwolenie. Zazwyczaj jest postrzegane jako głoszenie fałszywych twierdzeń, a przecież, pomimo że przyjmuje pozory prawdy, nie zawsze musi być synonimem fałszu, nawet jeśli akt kłamania stwarza po stronie odbiorcy fałszywe przeświadczenie. Niemniej jednak można wskazać, że w świecie istnieje dualizm prawdy i kłamstwa, będących prima facie swoimi przeciwieństwami. Niniejsza praca ma na celu analizę natury (istoty) kłamstwa z perspektywy pragmatyki logicznej, a dokładnie jej działu, jakim jest teoria aktów mowy oraz weryfikację wniosków w kontekście wybranych instytucji prawa cywilnego w celu ukazania, jak prawo i orzecznictwo postrzegają różne formy kłamstwa występujące na gruncie prawa pozytywnego.

Jadwiga Puzynina poruszyła zagadnienie genezy nazwy „kłamstwo” w języku polskim. Wywodzi się ono z epoki prasłowiańskiej, a możliwe, że nawet z praindoeuropejskiej. Jedna z koncepcji przyjmuje, że nazwa „prawda” nawiązuje do „prostości (prostolinijności)”, zaś „kłamstwo” jest synonimem „krzywości” (Bańkowski 2000, 761). Co więcej ,,prawda” pochodzi od czasownika „prawić”, który oznacza 'mówić to, co prawe', tj. 'proste'. Z kolei „kłamstwo” nawiązuje do „odchylenia od prostej”, które koresponduje z czasownikiem „giąć” lub

* Uniwersytet Łódzki, Wydział Prawa i Administracji, Katedra Teorii i Filozofii Prawa, joanna.anna.kolodziejczyk@gmail.com.

${ }^{1} \mathrm{~W}$ artykule będę posługiwała się wyrażeniami „kłamanie” i „kłamstwo” zamiennie, traktując pierwsze jako czynność, a drugie jako jej wytwór, zgodnie z tradycją zapoczątkowaną przez Kazimierza Twardowskiego. 
„zginać” (Puzynina 1992, 186). Taka etymologia słowa „kłamstwo” pokazuje, że już sama nazwa charakteryzuje zjawisko, które jest pewną anomalią w świecie rządzonym określonymi prawami, co do zasady gloryfikującymi ład i porządek.

„Prawda” nie ma powszechnie przyjętej definicji, nie jest również jasne, czy jest to pojęcie epistemologiczne, ontologiczne, czy też aksjologiczne. Najczęściej jednak analizy prawdy dokonuje się na gruncie teorii poznania (Woleński 2003, 25). Rozpowszechniony jest podział na definicje klasyczne i nieklasyczne prawdy. Do najbardziej znanych klasycznych definicji należą: Arystotelesowska, św. Tomasza z Akwinu oraz Alfreda Tarskiego. Za wiodące definicje nieklasyczne uważa się: teorię koherencyjności, teorię pragmatyczności, teorię ogólnej zgody (konsensualistyczną) i teorię jawności (bądź oczywistości). W języku potocznym często sformułowania: „definicja prawdy” oraz „koncepcja (teoria) prawdy” są używane zamiennie i traktowane synonimicznie. W rzeczywistości nie są one tożsame. Definicja prawdy zawiera formułę określającą ,prawdziwość” oraz podaje cechy definiowanego wyrażenia. Teoria prawdy zaś jest pojęciem szerszym. Składa się z definicji oraz twierdzeń, które wspólnie starają się opisać problematykę zagadnienia prawdy, równocześnie odnosząc się do innych teorii i często wchodząc z nimi w polemikę (Woleński 2003, 8).

W nawiązaniu do powyżej wskazanego podziału Arystoteles w dziele Metafizyka skonstruował jedną z najbardziej znanych definicji prawdy. Swoje rozważania oparł o badania relacji między poznaniem a rzeczywistością. Stwierdził, iż: „,[m]ówić, że to, co jest, nie jest, a to, co nie jest, jest, to fałsz, a mówić, że to, co jest, jest, a to, co nie jest, nie jest, to prawda" (Arystoteles 1983, 238). Oznacza to, że możemy stwierdzić prawdziwość jedynie tego, co można zobaczyć lub odczuć w rzeczywistości, innymi słowy - prawdziwe jest to, co ma odzwierciedlenie w rzeczywistości. Barry Allen stwierdza, że owa definicja opiera się na trzech założeniach: „żeby coś istniało, musi mieć formę, musi odnosić się do tożsamości danej materii i posługując się zrozumiałym językiem musi dać się określić. Teoria ta ujmuje prawdę w stosunku do natury, bytu i języka" (Allen 1994, 20). Jest to definicja, która $\mathrm{w}$ bardzo dużym stopniu łączy się z naturalnym postrzeganiem świata przez człowieka i odwołuje się do podstawowych obserwacji rzeczywistości, których on dokonuje. W związku z powyższym, w moim opracowaniu fenomenu kłamstwa posłużę się wyłącznie takim określeniem pojęcia prawdy, dlatego że kłamiąc właśnie, kreujemy swoim działaniem rzeczywistość, która sprawia pozory prawdziwości, ale $\mathrm{w}$ finalnym rezultacie prawdziwa nie jest.

W Arystotelesowskiej definicji nacisk kładzie się na zmysły człowieka, które mają mu pomóc odkryć, co jest prawdą. W przypadku skutecznego kłamstwa zmysły jego odbiorcy zostają wykorzystane w celu wprowadzenia w błąd, a co za tym idzie - odbiorca ma wrażenie, że słyszy prawdę, mimo że słyszy kłamstwo. Czy kłamstwo jest więc równoważne z fałszem? Zdecydowanie nie można postawić tak prostej tezy. Natura kłamstwa nie wiąże się bezpośrednio $\mathrm{z}$ fałszem, a jej istoty należy szukać gdzie indziej, co będzie tematem dalszych 
rozważań. Kłamstwo może przybierać różne formy: werbalne i niewerbalne. Kłamca korzysta ze wszystkich dobrodziejstw komunikacyjnych: mowy, milczenia, środków słownych i pozasłownych jako intersubiektywnych form analizowanych w ramach teorii aktów mowy.

Historycznie teoria aktów mowy została antycypowana teorią aktów społecznych. Zostały one wyodrębnione i poddane analizie fenomenologicznej w jednej z najsłynniejszych prac fenomenologicznych początków tego nurtu, a mianowicie w Apriorycznych podstawach prawa cywilnego Adolfa Reinacha. Reinach wyodrębnił szczególną kategorię aktów, które budują sferę relacji społecznych, a w szczególności normatywności. Określił je jako soziale Akte, czyli akty społeczne i zdefiniował jako „spontaniczne i wymagające przyjęcia do wiadomości” (Reinach 1989, 159). W oparciu o przywołaną definicję krystalizują się dwie cechy konstytutywne aktu społecznego. Po pierwsze, ma on miejsce między dwoma lub więcej podmiotami, które przekazują sobie pewną wiadomość/informację. Po drugie, owa wiadomość/informacja musi zostać przyjęta przez adresata wypowiedzi (Bekrycht 2011, 15). Bez przyjęcia do wiadomości nie ma pomiędzy podmiotami komunikacji. Komunikacja zaś, według Słownika języka polskiego, to ,przekazywanie i odbieranie informacji między podmiotami” (Doroszewski [b.r.]). Tak więc można wywnioskować, że podstawą komunikacji jest aktywność polegająca na spełnianiu aktów społecznych między podmiotami. Co ważne, ,uzewnętrznienie” aktu społecznego nie musi przejawiać się wyłącznie językowo, ale może objawiać się w dowolny sposób (Reinach 1989, 160). Podobne spostrzeżenia pojawiły się kilkadziesiąt lat później w pracach Johna L. Austina oraz Johna Searle'a. Austin wyodrębnił w swojej koncepcji trzy aspekty aktów mowy: lokucyjny, perlokucyjny i illokucyjny. Aspekt illokucyjny według Austina dotyczy intencjonalności wypowiedzi, stanowiąc równocześnie jej trzon. Sam akt lokucyjny to tworzenie i wypowiadanie wypowiedzi, a akt perlokucyjny dotyczy oddziaływania na odbiorcę, np. wywołanie w nim określonych emocji (Dutka 1991). Podział ten był impulsem do badań aktów mowy prowadzonych przez Johna Searle'a - ucznia Austina. Dla Searle'a filozofia języka jest jedną z gałęzi filozofii umysłu (Kołodziejczyk 2004, 214). Oznacza to, że nie można badać języka bez badania relacji zachodzących między językiem a umysłem. Język jest wręcz pochodną procesów zachodzących w umyśle człowieka, wyrazem jego intencji. Ale, jak stwierdza Tomasz Bekrycht: „Reinachowskie pojęcie aktu społecznego jest znacznie szersze niż Austinowskie czy Searlowskie pojęcie aktu mowy. Nie tylko język, ale i inne narzędzia komunikowania mogą posłużyć nam do spełnienia aktów społecznych" (Bekrycht 2009, 92-93). Kłamanie możemy zatem uznać za rodzaj aktu społecznego, który pełni szczególną rolę semiotyczną.

Co ciekawe, żadna ze wskazanych przez Romana Jakobsona funkcji języka, innymi słowy żadna $\mathrm{z}$ jego ról semiotycznych - tj. emotywna, poznawcza, poetycka, faktyczna, metajęzykowa, konatywna - nie odnosi się do funkcji języka jako nośnika kłamstwa (Jakobson 1960). Co więcej, pod żadną z wyodrębnionych 
funkcji nie da się podciągnąć aktu kłamania. Dla kłamiącego język jest narzędziem dokonania aktu kłamania, który można rozpatrywać na dwóch poziomach. Pierwszy poziom to kłamstwo wyrażone za pomocą języka do nadawcy, stwarzające w świadomości nadawcy poczucie poznania prawdziwego twierdzenia. Drugi poziom można umiejscowić w świadomości kłamiącego, gdzie rodzi się intencja i strategia kłamania.

Jak więc powstaje kłamstwo jako szczególny akt mowy? Na początku powstaje pewna myśl, która bezpośrednio łączy się z określoną intencją, inaczej mówiąc: celem wypowiedzi. Następnie człowiek, używając znanych mu znaków językowych i reguł gramatycznych, artykułuje określoną wypowiedź, kierując ją do adresata. Adresat wypowiedzi nie zna intencji nadawcy, czyli nie wie, że usłyszana wypowiedź jest kłamstwem, za pomocą której nadawca chce uzyskać szeroko pojętą korzyść. Tak więc cechą dystynktywną kłamstwa jest intencjonalne oszukanie kogoś lub zatajenie czegoś. Problemem staje się tu możliwość dotarcia do treści intencjonalnych nadawcy. Searle podkreśla, że „tą samą czynność wypowiadania można wykonać $\mathrm{z}$ wieloma różnymi intencjami, ważne by uświadomić sobie, że jedna i ta sama wypowiedź może stanowić wykonanie różnych czynności illokucyjnych" (Searle 1987, 95). Według słów Searle’a samo stwierdzenie może być wypowiedziane z różną intencją, a co za tym idzie, nie da się, słysząc samą treść wypowiedzi, określić, czy jest ona prawdziwa, czy jest może kłamstwem. Tak więc, gdy podmiot wypowiada zdanie „Wyglądasz świetnie w tym garniturze", nie można ocenić, czy zdanie to wypowiedziane zostaje zgodne z rzeczywistością, czy też jest tak zwanym białym kłamstwem, czyli kłamstwem grzecznościowym. By ocenić zdanie konkretnej osoby, trzeba znać jej intencję.

Jednak twierdzenie, że to intencja konstytuuje akt kłamania, nie jest powszechne. Do jego podważenia doszło w artykule Prototype Semantics: The English Word Lie Lindy Coleman i Paula Kaya. Podjęli oni próbę zdefiniowana i zanalizowania kłamstwa, bazując na teorii prototypów. Ich definicja kłamstwa brzmiała: „niech P będzie dowolnym zdaniem, które N (nadawca) wypowiada do O (odbiorcy). N kłamie wtedy, gdy P jest fałszywe, $\mathrm{N}$ wierzy, że P jest fałszywe, wypowiadając P, N zamierza oszukać O" (Coleman, Kay 1981, 28). Prototyp kłamstwa posiada zatem według nich trzy cechy: fałszywość, intencjonalność fałszywości i zamiar oszukania, jednakże nie one muszą występować symultanicznie. Ponadto nie zachodzi między nimi żadna hierarchiczność. Kłamstwem może być wypowiedź, która posiada chociaż jedną ze wskazanych cech (Coleman, Kay 1981, 29). Jest to niezwykle kontrowersyjna hipoteza. Dla Coleman i Kaya np. kłamstwa grzecznościowe są wypowiedziami fałszywymi, co bezpośrednio stanowi o ich kłamliwej naturze, pomimo braku bezpośredniej intencji oszukania interlokutora. A przecież grzeczność może wynikać z odruchu bezwarunkowego, nabytego już w latach dziecięcych, kiedy to byliśmy uczeni, by chociażby po posiłku pochwalić obiad przygotowany przez gospodarza. Jolanta Antas takie 
kłamstwa kwalifikuje jako kłamstwa społeczne i równocześnie podkreśla, że wymykają się one ze społecznych wyobrażeń kłamstwa (Antas 2000, 140).

Następnie Coleman i Kay przeprowadzili eksperyment, który bazował na przygotowanych kwestionariuszach, składających się z 8 opowieści. Do każdej opowieści było gotowych 7 odpowiedzi, które miały wykrystalizować „,stopień kłamstwa” oraz „stopień pewności informacyjnej, że dana opowieść jest kłamstwem". Przebadano 67 osób (Coleman, Kay 1981, 30). W wyniku badań dokonano gradacji elementów prototypowych kłamstwa. Pierwsze miejsce zajęła wiara w fałsz, następnie zamiar oszukania, a trzecie miejsce fałsz rzeczywisty (Coleman, Kay 1981, 35). Wnioski wyciągnięte na podstawie wykonanych badań mogą być wątpliwe ze względu na niewielką liczebność grupy badawczej. Poza tym, nawiązując do przytoczonego wcześniej przykładu, nawet gdy człowiek chwali obiad gospodarza z grzeczności, kierując się „kulturalnym zachowaniem”, tak naprawdę ma świadomość, że go oszukuje. Nie jest ważne, czy intencja wiąże się z odczuciami pozytywnymi, tj. stworzeniem dobrej relacji z daną osobą, czy wprowadzeniem miłej atmosfery po obiedzie. Ponadto w tego typu eksperymentach ludzie mogą podświadomie odpowiadać tak, by było to bardziej akceptowane społecznie.

Anna Wierzbicka zarzuciła przytoczonemu eksperymentowi brak elementu wartościowania etycznego: „to źle” (Wierzbicka 1990). Negatywna ocena kłamstwa jest w jej mniemaniu cechą samego kłamstwa. Głównym zarzutem wobec takiego punktu widzenia jest mieszanie definicji semantycznej ze sferą moralności. Taki zabieg może faktycznie dawać większą optykę na wyjaśnienie istoty kłamstwa, miesza jednak dwie bardzo odmienne sfery. Stwierdzenie ,to źle” nawiązuje do powszechnego ostracyzmu społecznego kłamstwa. W pewnym sensie odwołuje się do podstaw kulturowych społeczeństwa, wedle których kłamstwo jest czynem nagannym. Rozważania natury moralnej z pewnością są istotnym elementem badań dotyczących kłamstwa, lecz nie mają bezpośredniego związku $\mathrm{z}$ warstwą semantyczną tego zagadnienia.

Analizy Coleman, Kaya oraz Wierzbickiej do tej pory nie pozwalają nam wykrystalizować naczelnej cechy kłamstwa. Wróćmy zatem do rozważań skupiających się na intencji jako podstawie kłamstwa. Searle w dziele Speech acts. An essay in the philosophy of language wyróżnił występowanie aktów bezpośrednich i aktów pośrednich. Akty bezpośrednie to takie, w których intencję można od razu stwierdzić i jest niezmienna, na przykład „Podaj mi cukier”. Wypowiadający kieruje swoją wypowiedź do nadawcy i jego intencją jest otrzymanie cukru. Akty pośrednie z kolei mają nieoczywiste intencje, na przykład „Pięknie wyglądasz w tej sukience”. Takie stwierdzenie może być zgodne z prawdą albo wręcz przeciwnie - może być tzw. białym kłamstwem. Żeby odczytać intencję, musimy znać kontekst, czyli tło danego stwierdzenia. Reinach zauważa, że „sposób mówienia, akcentowania, ostrość i tym podobne” nadają właściwą formę określonemu aktowi mowy (Reinach 1989, 161). W innym miejscu pisze 
on o „towarzyszących okolicznościach”, które „nie pozostawiają adresatowi żadnej wątpliwości, co do charakteru aktu społecznego, który się w nim przejawia" (Reinach 1989, 166). Bez poznania towarzyszących okoliczności nie jesteśmy w stanie stwierdzić, czy coś kłamstwem jest, czy też nie. Jak podkreśla Tomasz Bekrycht: „Wydaje się, że zawsze rdzeniem aktu, który przesądza o jego tożsamości będą owe intencjonalne przeżycia, które czasami muszą być identyfikowane w oparciu o inny niż językowy przejaw tego aktu" (Bekrycht 2009, 95). Dodatkowo można też wskazać na taki element, jak emocje towarzyszące wypowiadanemu zdaniu. Często to one zdradzają prawdziwe myśli kłamcy. Akt mowy nie jest przecież mechaniczną wypowiedzią robota, tylko człowieka, który w zdaniach może zawrzeć szereg przeżyć.

Kontekst służy więc interpretacji danego stwierdzenia, prawdziwa intencja świadczy zaś o jego naturze - to ona przesądza, czy stwierdzenie jest kłamstwem, czy też nie. Tym bardziej, że o ile akty „obiecywania”, „proponowania” itp. dają możliwość wyodrębnienia charakterystycznych dla nich zwrotów językowych, o tyle akt kłamania nie ma żadnej charakterystycznej formuły językowej (Antas 2000, 163). To określona intencja konstytuuje powstanie kłamstwa, nie zaś jakakolwiek forma na gruncie językowym. Co ciekawe, Andrzej Malinowski wskazuje, że istnieją wypowiedzi, które mogą nigdy nie zostać zakwalifikowane jako kłamstwo. Stwierdza, iż w przypadku, gdy nadawca wypowiedzi posługuje się czasownikiem epistemicznym, np. „sądzę, że...”, ,,jestem pewien, że...”, „wierzę, że...", nie jest możliwe przypisanie wartości logicznej takim wyrażeniom, tj. określenie, czy są one prawdziwe, czy też fałszywe, i tylko nadawca wypowiedzi może stwierdzić, jaką wartość logiczną ma jego wypowiedź (Malinowski 2014).

Jak więc odczytać daną intencję, skoro dobre i skuteczne kłamstwo sugeruje nam określoną intencję nadawcy, a prawdziwa jest dla nas ukryta. Kłamstwo wiąże się bezpośrednio z aktem „nieszczerym”, czy też inaczej - „pozornym”. Nie można bazować wyłącznie na „semantycznych przesłankach”, ponieważ nie ukażą one prawdziwej intencji nadawcy. Użycie określonego czasownika przez nadawcę wypowiedzi nie musi wyrażać charakterystycznej intencji z nim związanej (Antas 2000, 164). Trudno jednak mając do czynienia z kłamstwem, wykrystalizować kryteria, aby je zidentyfikować, ponieważ wymyka się ono wszelkim regułom. Reinach pisze, że akty społeczne „mają wewnętrzną i zewnętrzną stronę, jakby duszę i ciało" (Reinach 1989, 160). To samo możemy odnieść do aktów mowy - ich zewnętrzna strona jest nam znana dzięki znakom językowych, wewnętrzna zaś wymaga odwołania się do wspominanego wyżej kontekstu oraz intencji. Z kolei Austin wiązał kłamstwo z nieszczerością oraz faktem zachodzenia myśli (Austin 1993, 587-588). Nieszczerość jest stwarzaniem pozornej rzeczywistości, a zachodzenie myśli obrazuje sytuacje, gdy twierdzenie wypowiadane nie jest tym samym twierdzeniem, o którym myśli kłamca. Wypowiada on kłamliwe twierdzenie celowo. Paul Ekman w książce Kłamstwo i jego wykrywanie w biznesie, polityce, matżeństwie wskazał: „Osoba, która kłamie, jest w stanie wybrać pomiędzy 
kłamstwem lub mówieniem prawdy i pojmuje między nimi różnicę" (Ekman 1997, 27). Tak więc kłamiący ma pełną świadomość aktu kłamania, godzi się na to i dokonuje aktu intencjonalnie.

Rozpoznanie intencji jest z pewnością rdzeniem wypowiedzi. Nie ulega też wątpliwości, że często istnieje sprzeczność między intencją a semantycznymi przesłankami (Bekrycht 2009, 102). Związki, które zachodzą między wypowiedzianymi znakami językowymi a rzeczywistością mogą de facto nie mieć znaczenia, jeśli intencja jest inna. Intencja wymyka się semantyce, a odwołuje do sfery moralności i psychologii postępowania człowieka. Kontekst zaś często odwołuje się do źródeł kulturowych. Marek Zirk-Sadowski stwierdził:

kontekst wykazuje regularności związane z kulturowymi cechami zbiorowości społecznej. Prawidłowości tego typu działają zarówno na poziomie makrostruktury społecznej, jak również w małych, nieformalnych grupach. W swej genezie i zasadach funkcjonowania są one niezależne od wewnętrznych prawidłowości języka kodu, ponieważ są wytworem społecznych konwencji, które organizują przebieg ludzkich zachowań (Zirk-Sadowski 1984, 72).

Intepretując więc akty mowy i chcąc w pełni je zrozumieć, należy znać konwencję, która leży u podstaw wypowiedzi. Konwencja charakteryzuje określoną grupę społeczną oraz pozwala zrozumieć kontekst sytuacyjny, ponieważ wpływa na sposób wypowiadania aktów mowy, tj. komunikowania się ludzi.

Powyższe rozważania pokazują, że interpretacja stwierdzeń przekazywanych za pomocą aktów mowy tylko na poziomie językowym, za pomocą semantycznych przesłanek, może nie ukazać w pełni faktycznej treści wypowiedzi. Jak już wspomniałam, semantyka to tylko zewnętrzna strona stwierdzenia, wewnętrzna odnosi się do sfery pozajęzykowej. Sfera pozajęzykowa to kontekst, który za każdym razem wymaga głębszych badań nad konwencją, kulturą, tłem wypowiedzi, emocjami towarzyszącymi. Najważniejsza jednak jest intencja nadawcy, która nie jest tożsama z kontekstem. Intencja jest najgłębszym poziomem wypowiedzi, jej immanentną częścią. Łączy się bezpośrednio ze wszystkimi procesami umysłowymi człowieka. Nie jest samoistna tylko wyraża poglądy, przekonania, pragnienia, cele człowieka. Nie ma środków ani metodologii badania intencji. Za każdym razem taka analiza wymaga indywidualnego podejścia i dogłębnej interpretacji.

Przenosząc rozważania na płaszczyznę prawną, analiza kłamstwa na gruncie teorii aktów społecznych i teorii aktów mowy ma szczególne znaczenie przy problematyce wykładni oświadczeń woli. Oświadczenie woli można zaklasyfikować jako szczególną formę aktu mowy, która wywołuje skutki w sferze prawnej. Należy podkreślić, że oświadczenie woli może wywołać określony skutek dopiero, gdy zostanie odebrane przez adresata (Radwański 1997, 164). Bez tego aktu nie można mówić o skuteczności oświadczenia woli.

W pierwszej kolejności konieczne jest udzielenie odpowiedzi na pytanie o to, czemu ma służyć wykładnia oświadczeń woli. Zbigniew Radwański wskazuje, że „wykładnia ma na celu pod względem prawnym poznać treść oświadczenia 
woli, a więc, jakiej treści są jej prawa i obowiązki stąd wynikające dla podmiotów prawa cywilnego" (Radwański 1992, 20). Można zatem stwierdzić, że wykładnia odkodowuje oświadczenie woli, kładąc nacisk na skutki, które wywołuje na gruncie prawa.

W polskim prawodawstwie art. $65 \S 1$ ustawy z dnia 23 kwietnia 1964 r. - Kodeks cywilny (tekst jedn. Dz.U. z 1964 r. Nr 16, poz. 93 ze zm.; dalej: k.c.) stwierdza, że „oświadczenie woli należy tak tłumaczyć, jak tego wymagają ze względu na okoliczności, w których złożone zostało, zasady współżycia społecznego oraz ustalone zwyczaje". Owe okoliczności łączą się bezpośrednio z omawianym powyżej kontekstem oraz intencją.

Podstawowe znaczenie dla interpretacji oświadczeń woli mają dyrektywy językowe, tj. badanie oświadczenia pod kątem użytych słów i ich powszechnego znaczenia. Podczas kolejnych etapów edukacji dziecko uczy się języka i sposobu posługiwania się nim w określonej społeczności. Jest to szeroko pojęta socjalizacja. Interpretując więc wyrażenie na gruncie językowym, należy odwołać się do reguł panujących w danej społeczności, język jest bezpośrednio związany z kulturą danej wspólnoty (Ziółkowski 1979, 228-229). Poznanie reguł znaczeniowych umożliwia poznanie i interpretację wyrażenia, które uzewnętrznia określone myśli danej osoby (Ziembiński 1984, 12).

Gdy dyrektywy językowe nie są wystarczające w procesie wykładni, należy wziąć pod uwagę kontekst językowy, czyli dane oświadczenie rozpatrywać na gruncie całej, szerszej wypowiedzi. Jak zauważa Anna Jędrzejewska, „kontekst sytuacyjny powinien znać zarówno oświadczający, jak i odbiorca" (Jędrzejewska 1992, 186). Kolejna dyrektywa skupia się na analizie celowości dokonania określonej czynności prawnej (Radwański 1997, 208). Jest to ogólnie przyjęta hierarchiczność dyrektyw służących do interpelacji oświadczeń woli. Sąd Najwyższy w wyroku z dnia 16 listopada 2018 r. stwierdził:

W świetle art. $65 \S 1$ k.c. dla prawidłowej wykładni oświadczeń woli, także jeżeli są one objęte dokumentem, znaczenie ma nie tylko wynik analizy językowej, lecz również kontekst sytuacyjny, w jakim składane są oświadczenia, w tym ustalenia prowadzące do wypracowania i ostatecznego sformułowania tekstu dokumentu. Jest tak zwłaszcza wtedy, gdy analiza językowa oświadczenia, z uwzględnieniem całej jego treści, nie prowadziła do jednoznacznych rezultatów (I CSK 668/17).

Tym samym, na przykładzie powyższego orzeczenia, Sąd Najwyższy ukazuje, jak ważne jest zrozumienie oświadczenia woli nie tylko na poziomie językowym, ale też w szerszej perspektywie, czyli tła złożenia danego oświadczenia woli.

Analiza problematyki interpretacji oświadczeń woli łączy się nierozerwalnie z instytucją prawną, jaką są wady oświadczeń woli. Kodeks cywilny enumeratywnie je wymienia: brak świadomości i swobody, pozorność, błąd, podstęp i groźba. Wydaje się, że z punktu widzenia analizy fenomenu kłamstwa 
najistotniejsze są pozorność i podstęp. W jakich zatem formach akty kłamania występują na gruncie prawa? Warto podkreślić, że przecież sama nazwa „kłamstwo" nie należy do nomenklatury ani języka prawnego, ani prawniczego.

Jak stwierdza Biruta Lewaszkiewicz-Petrykowska: „Pozorność prowadzić może do niepewności w obrocie, podważenia zaufania do podejmowanych czynności, nierzadko też dokonywana jest w celu zamaskowania postępowania niezgodnego z prawem" (Lewaszkiewicz-Petrykowska 1973, 48). W art. 83. § 1 k.c. jest zapisane: „Nieważne jest oświadczenie woli złożone drugiej stronie za jej zgodą dla pozoru. Jeżeli oświadczenie takie zostało złożone dla ukrycia innej czynności prawnej, ważność oświadczenia ocenia się według właściwości tej czynności”. Przy pozorności ważne jest, aby strona, wobec której złożono pozorne oświadczenie woli, wiedziała o tym i na to się godziła. Pozornością nie jest tzw. reservatio mentalis, czyli zastrzeżenie potajemne. W tym wypadku druga strona nie wie o braku zamiaru wywołania skutków prawnych, przez co nie ma możliwości wyrażenia zgody na takie działanie (Lewaszkiewicz-Petrykowska 1973, 55). Podstawą jest zatem, by druga strona wiedziała o braku woli do wywołania skutków prawnych i akceptacja tego działania. Można więc postawić tezę, że przy pozorności obie strony kłamią, gdyż intencją obu stron jest kłamanie. Taka interpretacja ma odzwierciedlenie w wyroku Sądu Apelacyjnego w Katowicach z dnia 13 kwietnia 2017 r., w którym wskazano, co następuje:

Oświadczenie woli złożone jest dla pozoru wtedy, gdy z góry powziętym zamiarem stron brak jest woli wywołania skutków prawnych, przy jednoczesnej chęci wprowadzenia innych osób (lub organów władzy) w błąd, co do rzekomego dokonania określonej czynności prawnej. Pozorność jako wada oświadczenia woli polega na niezgodności między aktem woli a jej przejawem na zewnątrz, przy czym strony zgodne są co do tego, aby wspomniane oświadczenie nie wywołało skutków prawnych (I ACa 1165/16).

Przywołane orzeczenie ukazuje intencje pozorności, to jest brak wywołania skutków prawnych oraz chęć wprowadzenia innych w błąd, jest to równoznaczne ze stworzeniem nieprawdziwego obrazu rzeczywistości. Zatem wyraźnie można dostrzec rozbieżność pomiędzy wolą rzeczywistą a oświadczoną podmiotu. Jednocześnie takie działanie jest sprzeczne z naturą oświadczenia woli, tj. brakiem zamiaru wywołania określonego skutku prawnego (Lewaszkiewicz-Petrykowska 1973, 50).

Podstęp z kolei jest unormowany w art. 86 k.c. Jest to świadome wywołanie u drugiej osoby błędnego obrazu rzeczywistości lub umocowanie jej błędnego mniemania po to, by skłonić ją do złożenia oświadczenia woli określonej treści. Przemilczenie określonych informacji, gdy istnieje obowiązek ich udzielenia, również jest kategoryzowane jako podstęp (Radwański 1997, 227). Sąd Najwyższy w wyroku z dnia 10 września 1997 r. (I PKN 251/97) jednoznacznie stwierdza: „do uchylenia się od skutków prawnych oświadczenia woli złożonego pod wpływem błędu wywołanego podstępem wystarczy, aby błąd dotyczył 
sfery motywacyjnej stanowiącej przyczynę złożonego oświadczenia woli”. Tak więc cechą konstytutywną podstępu jest podjęcie jakichkolwiek działań, które wpływają na złożenie określonego oświadczenia woli przez inny podmiot. Nie jest ważne, jak duże, fałszywe przekonanie powstanie w świadomości podmiotu (Lewaszkiewicz-Petrykowska 1973, 50).

Wskazane orzeczenie pokazuje, jak wielkie znaczenie ma składanie oświadczenia woli przez podmiot, który ma wiedzę i świadomość co do prawdziwej rzeczywistości, a nie takiej, która tylko posiada znamiona prawdy.

W dalszej części wyroku z dnia 9 września 2004 r. Sąd Najwyższy stwierdził:

Powszechnie przyjmuje się, że działanie podstępne polega na świadomym wywołaniu u drugiej osoby mylnego wyobrażenia o rzeczywistym stanie rzeczy po to, aby skłonić ją do dokonania określonej czynności prawnej. Działanie podstępne jest zawsze naganne z punktu widzenia ocen etycznych, gdyż zakłóca w niedopuszczalny sposób proces decyzyjny innej osoby, doprowadzając tę osobę na podstawie zasugerowanych jej fałszywych przesłanek rozumowania do dokonania określonej czynności prawnej. Ujemna etycznie ocena każdego podstępu stała się motywem surowego potraktowania przez prawo cywilne skutków wywołanego nim błędu, dlatego uchylenie się od skutków prawnych oświadczenia woli złożonego pod wpływem podstępu może nastąpić także wtedy, gdy błąd nie był istotny, jak również wtedy, gdy nie dotyczył treści czynności prawnej (II CK 498/03).

Orzeczenie to uwypukla, iż podstęp posiada wszystkie poruszane znamiona kłamstwa, czyli intencjonalne kierowanie nieprawdziwych twierdzeń do innego podmiotu (adresata) w celu osiągnięcia szeroko pojętych korzyści, dzięki podjęciu przez adresata określonych czynności prawnych, bazujących na fałszywym obrazie rzeczywistości.

Jak widać, zarówno w przypadku pozorności, jak i podstępu, musi ujawnić się wola rzeczywista podmiotu, która jest tożsama z intencją podmiotu. Jest nią w każdym przypadku skłamanie, czyli stworzenie pozorów prawdy za pomocą semantycznych przesłanek. Kłamstwo ma prowadzić do uzyskania określonych korzyści.

Podsumowując, należy stwierdzić, że trudno jest zbudować satysfakcjonującą definicję kłamstwa, która w pełni wyrażałaby jego naturę. Stosuje się tu zwykle metodologiczny zabieg opisu jawiących się fenomenów oraz ich analizę. Niemniej jednak jako cechę konstytuującą akt kłamania można (jak w każdym akcie mowy) wskazać intencjonalność podmiotu kłamiącego. To świadoma decyzja o stworzeniu pozornej rzeczywistości świadczy o akcie kłamania. Ponadto uregulowane w Kodeksie cywilnym instytucje pozorności oraz podstępu to zjawiska potocznie określane jako kłamstwo. Do tego można dodać, że za każdym razem, co wyraża orzecznictwo, jest ono niezwykle negatywnie postrzegane. 


\section{BIBLIOGRAFIA}

Allen, Barry. 1994. Prawda w filozofii. Warszawa: Wydawnictwo Instytutu Filozofii i Socjologii PAN. Antas, Jolanta. 2000. O ktamstwie i kłamaniu. Kraków: Towarzystwo Autorów i Wydawców Prac Naukowych Universitas.

Arystoteles. 1983. Metafizyka. Warszawa: Państwowe Wydawnictwo Naukowe.

Austin, John. 1993. Mówienie i poznawanie. Rozprawy i wyklady filozoficzne. Warszawa: Wydawnictwo Naukowe PWN.

Bańkowski, Andrzej. 2000. Etymologiczny słownik języka polskiego. Warszawa: Wydawnictwo Naukowe PWN.

Bekrycht, Tomasz. 2009. Aprioryczność prawa: ontologia prawa w fenomenologii Adolfa Reinacha. Warszawa: Wolters Kluwer Polska.

Bekrycht, Tomasz. 2011. „O wartości logicznej normy prawnej”. Studia Prawno-Ekonomiczne 84: $11-38$.

Coleman, Linda, Paul Kay. 1981. „Prototype Semantics: The English Word Lie”. Language 57 (1): $26-44$.

Doroszewski, Witold (red.). [b.r.]. „Komunikacja” [hasło]. W Słownik języka polskiego. Warszawa: Polskie Wydawnictwo Naukowe. https://sjp.pwn.pl/szukaj/komunikacja;5441377.html [dostęp 15.01.2018].

Dutka, Anna. 1991. „Ku dynamicznej koncepcji języka. Teorie Jean-Claude’a Anscombre'a i Oswalda Ducrota". Pamiętnik Literacki 3 (82): 158-171.

Ekman, Paul. 1997. Kłamstwo i jego wykrywanie w biznesie, polityce, matżeństwie. Warszawa: Wydawnictwo Naukowe PWN.

Jakobson, Roman. 1960. „Poetyka w świetle językoznawstwa”. Pamiętnik Literacki 2 (51): 431-473.

Jędrzejewska, Anna. 1992. Koncepcja oświadczenia woli w prawie cywilnym. Warszawa: Agencja Scholar.

Kołodziejczyk, Piotr. 2004. „Johna Searle’a teoria intencjonalności”. W Intencjonalność jako kategoria filozofii umystu i filozofii języka. Red. Zbysław Muszyński, Jacek Paśniczek. 203-235. Lublin: Wydawnictwo Uniwersytetu Marii Curie-Skłodowskiej.

Lewaszkiewicz-Petrykowska, Biruta. 1973. Wady oświadczenia woli w polskim prawie cywilnym. Warszawa: Wydawnictwo Prawnicze.

Malinowski, Andrzej. 2014. „Kłamstwo a fałszywe zeznanie”. Edukacja Prawnicza 5 (152). http:// www.edukacjaprawnicza.pl/klamstwo-a-falszywe-zeznanie/ [dostęp 17.03.2018].

Puzynina, Jadwiga. 1992. Język wartości. Warszawa: Wydawnictwo Naukowe PWN.

Radwański, Zbigniew. 1992. Wykładnia oświadczeń woli składanych indywidualnym adresatom. Wrocław: Zakład Narodowy im. Ossolińskich.

Radwański, Zbigniew. 1997. Prawo cywilne - część ogólna. Warszawa: Wydawnictwo C.H. Beck.

Reinach, Adolf. 1989. Sämtliche Werke. Monachium: Philosophia Verlag.

Searle, John. 1987. Czynności mowy. Warszawa: PAX.

Wierzbicka, Anna. 1990. „'Prototypes save': On the uses and abuses of the notion of 'prototype' in linguistics and related fields". W Meaning and prototypes. Studies in linguistic categorization. Red. Savas L. Tsohatzidis. 374-367. London: Routledge \& Kegan Paul.

Woleński, Jan. 2003. Epistemologia. T. 3: Prawda i Realizm. Kraków: Aureus.

Ziembiński, Zygmunt. 1984. Logika praktyczna. Warszawa: Państwowe Wydawnictwo Naukowe.

Ziółkowski, Marek. 1981. Znaczenie. Interakcja. Rozumienie. Studium z symbolicznego interakcjonizmu i socjologii fenomenologicznej jako wersji socjologii humanistycznej. Warszawa: Państwowe Wydawnictwo Naukowe.

Zirk-Sadowski, Marek. 1984. Rozumienie ocen w języku prawnym. Łódź: Uniwersytet Łódzki. 


\section{Akty prawne}

Ustawa z dnia 23 kwietnia 1964 r. - Kodeks cywilny (tekst jedn. Dz.U. z 1964 r. Nr 16, poz. 93 ze zm.).

\section{Orzecznictwo}

Wyrok Sądu Apelacyjnego w Katowicach z dnia 13 kwietnia 2017 r., sygn. akt I ACa 1165/16, LEX nr 2287388.

Wyrok Sądu Najwyższego z dnia 10 września 1997 r., sygn. akt I PKN 251/97, OSNP 1998/13/389.

Wyrok Sądu Najwyższego z dnia 9 września 2004 r., sygn. akt II CK 498/03, LEX nr 137573.

Wyrok Sądu Najwyższego z dnia 16 listopada 2018 r., sygn. akt I CSK 668/17, LEX nr 2578185.

\section{Joanna Kołodziejczyk}

\section{LYING AS AN ACT OF SPEECH - A FEW REMARKS FROM A PHILOSOPHICAL AND LEGAL PERSPECTIVE}

Abstract. The article presents issues concerning the analysis of the nature (essence) of lies from the perspective of logical pragmatics. The conclusions were confronted with selected institutions of civil law, in order to show how law and jurisprudence perceive different forms of "lies" occurring on the basis of positive law.

Keywords: lie, act of speech, truth, intention, civil code. 